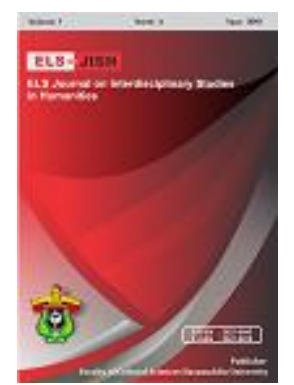

ELS-JISH

ELS Journal on Interdisciplinary Studies on Humanities

Volume 2 Issue 4, 2019

ISSN (print) : 2621-0843

ISSN (online) : 2621-0835

Homepage : http://journal.unhas.ac.id/index.php/jish

\title{
The Influence of Motivation on EFL Learners' Speaking Skills
}

\author{
Wira Kafryawan ${ }^{1}$ \\ 1wira.kafryawan@gmail.com
}

\begin{abstract}
Motivation is one of some psychological factors which influences the speaking proficiency. Therefore, this study aims at finding out whether or not there is a significant correlation between EFL learners' motivation and their speaking skills. With regard to the methodology applied in this study, a correlation research was used to determine whether, and to what degree, a relationship exists between two or more quantifiable variables in form of quantitative method. Purposive sampling was used in the correlational research due to the assumption that the selected students were able to give information or data in relation to the research problems based on the research design. Thus, 46 learners were chosen as the samples. The study was conducted at learners in SMA Negeri 1 Marisa, Pohuwato Regency, Gorontalo. Moreover, the quantifiable data were obtained from speaking test based on the Heaton assessment and motivation test based on the Likert Scale assessment which were distributed to the learners. The data were then analyzed by Pearson product moment. The findings showed that there was a significant correlation between EFL learners' motivation and their speaking skills in degree of high correlation. In other words, the assumption views that that the higher motivation belongs to EFL Learners to speak the better ability they speak.
\end{abstract}

Keywords: Motivation, Speaking Skills, EFL learners

How to cite: Kafryawan, W. (2019). The Influence of Motivation on EFL Learners' Speaking Skills. ELS Journal on Interdisciplinary Studies in Humanities, 2(4), 612-619

\section{Introduction}

English is one of tools of communication. In global communication, people communicate with others through English and they interact to make transaction or maintain interpersonal relationship. In a normal situation, people prefer communicating by spoken language to communicating by written language. According to Candlin and Hall (2008), speaking is the use of an ordinary voice, offering words, knowing and being able to use a language expressing oneself in words, and making speech. Moreover, speaking uses words and produces the sounds to express ideas, feeling, thought, and needs orally in an ordinary voice. Nunan (1991) stated that mastering the art of speaking is the single most important aspect of learning the second or foreign language, and success is measured in terms of the ability to carry out the language conversation in language.

In pedagogic focus, speaking is one of the four basic skills in learning English besides listening, reading, and writing. It has been taught to EFL learners from the elementary level to the university level even though in current regulation of K13,

\footnotetext{
${ }^{1}$ Universitas Pohuwato, Indonesia
} 
English subject of elementary level has been abolished temporarily from the curriculum. But speaking is still an essential skill to be learned by EFL learners in learning English.

Different perceptions about speaking skills come in every EFL learner. Most of EFL learners assume speaking is very difficult to master. Reinsch and Shelby (1996) stated that learners have overwhelmingly indicated that to improve their oral communication skills, one of their greatest needs is more self-motivation. Moreover, learning how to speak means something different because of dealing not only with the efforts of the learners to know the patterns of speaking but also the psychological problems inside themselves. In other words, psychological factors influence EFL learners in learning speaking.

Focus on the psychological factors influencing EFL learners in learning speaking, Littlewood (1984) stated that a persons' motivation to learn and the qualities of the opportunities to learn are two of these factors. The third set of factors is those which make up the person's ability to learn. The statement refers to motivation, environment and intelligence. Therefore, sets of factors is assumed that can influence how successful a learner to get a good competence in speaking.

Furthermore, Brown (2001) stated that one of the more complicated problems of second languages learning and teaching has been to define and apply the construct of motivation in the classroom. In general of all kinds of learning, motivation is among the fundamental factors which a learner should maintain throughout the learning process related to the speaking proficiency (Top, 2009). Some previous studies about motivation have been related to the pedagogical approach. The positive contribution of a number of strategies to improving language learners' motivation has been proven by numbers of research studies. Montazeri \& Salimi (2019) studied about assessing motivation to speak (MTS) and willingness to communicate through metalinguistic corrective feedback; Kazakova \& Shastina (2019) studied about the impact of socio-cultural differences on formation of intrinsic motivation; Keshavarzi \& Amiri (2016) studied about The effect of teachers' personality and corrective feedback on EFL learners' motivation; Mehregan \& Jafari-Seresht (2014) studied about the role of teacher feedback in enhancing leaner self-efficacy and motivation.

From the findings above, it is essential to conduct the further study about relationship between speaking skills and motivation related to how significant the influence of motivation towards EFL learners' speaking skills is. Thus, the objective in the study is to find out whether or not there is a significant correlation between EFL learners' motivation and their speaking skills.

\section{Method}

Correlational method involves collecting data to determine degree of relationship existing between two or more quantifiable variables. This study adopts correlational method design which is calculated in quantitative form.

\subsection{Source of Data}

The study was conducted in SMA Negeri 1 Marisa, Pohuwato Regency, Gorontalo. SMA Negeri 1 Marisa as a senior high school was able to represent entirely population and sample of the study. 


\subsection{Data Collection}

The data were analyzed by purposive sampling involving 46 EFL learners divided into 20 males and 26 females. The data were collected by using motivation test and speaking test. The first quantifiable data were found from motivation test based on the Likert Scale assessment. EFL learners were given some questionnaires about motivation. Score criteria of motivation were pointed in the range from low motivation $(20-60)$ and high motivation $(61-100)$. Moreover, questionnaires of motivation consist of positive and negative statements. The second quantifiable data were found from speaking test based on the Heaton assessment. It was conducted by oral form to obtain the current data. EFL learners were given narration subject. Then, they were asked to perform their speech in English in relation to their experiences. To analyze the second data, EFL learner speaking performance was recorded to obtain audio files. The scores were taken in four criteria involving the scores of grammar, pronunciation, vocabulary, and fluency. Finally, to get the mean, the scores from criteria were summed and divided into four. Furthermore, inter-rater reliability was used to make the speaking scores more objective.

\subsection{Data Analysis}

Pearson product moment was used to analyze data of motivation and speaking skills. The results within a certain range on first variable are connected with the results within a certain range on the second variable. It means that the Pearson product moment was used to analyze the significance of existing relationship data between scores of EFL learners' motivation and scores of their speaking skills.

$$
\begin{aligned}
& \sum X Y-\frac{\left(\sum X\right)\left(\sum Y\right)}{N} \\
& \sqrt{\left[\sum X^{2}-\frac{\left(\sum X\right)^{2}}{N}\right]\left[\sum Y^{2}-\frac{\left(\sum Y\right)^{2}}{N}\right]} \\
& r \quad=\text { correlation coefficient } \\
& N \quad=\text { number of respondents } \\
& X \quad=\text { distribution of EFL learners' motivation } \\
& Y=\text { distribution of EFL learners' speaking skills } \\
& \sum X=\text { total score of EFL learners' motivation } \\
& \sum Y=\text { total score of EFL learners' speaking skills } \\
& \sum X^{2}=\text { the sum of the square from Variable } X \\
& \Sigma Y^{2}=\text { the sum of the square from Variable } Y \\
& \sum X Y=\text { total number of } X \text { multiplied by } Y
\end{aligned}
$$

(Gay et al., 2006)

\section{Findings}

Based on the objective of the study to find out whether or not there is a significant correlation between two quantifiable variables, both data of EFL learners' motivation and data of their speaking skills were correlated by using Pearson Product Moment. After being calculated, result of the calculation in Table 1 showed that $\mathrm{N}$

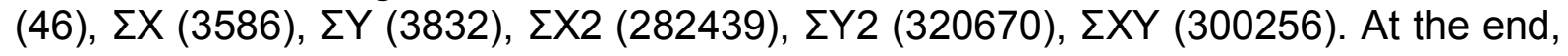
it was found out that the correlation coefficient (ro) is 0.73 . 
Table 1. Data of the Correlation between Motivation and Speaking Skills

\begin{tabular}{|c|c|c|c|c|c|}
\hline No & $\mathbf{X}$ & $\mathbf{Y}$ & $\mathrm{X}^{2}$ & $\mathbf{Y}^{2}$ & $\mathbf{X Y}$ \\
\hline 1 & 74.0 & 80.0 & 5476.0 & 6400.0 & 5920.0 \\
\hline 2 & 67.3 & 76.0 & 4529.2 & 5776.0 & 5114.8 \\
\hline 3 & 71.3 & 80.0 & 5083.6 & 6400.0 & 5704.0 \\
\hline 4 & 97.3 & 90.0 & 9467.2 & 8100.0 & 8757.0 \\
\hline 5 & 78.6 & 85.0 & 6177.9 & 7225.0 & 6681.0 \\
\hline 6 & 78.0 & 85.0 & 6084.0 & 7225.0 & 6630.0 \\
\hline 7 & 76.0 & 82.0 & 5776.0 & 6724.0 & 6232.0 \\
\hline 8 & 93.3 & 87.0 & 8704.8 & 7569.0 & 8117.1 \\
\hline 9 & 88.0 & 85.0 & 7744.0 & 7225.0 & 7480.0 \\
\hline 10 & 82.0 & 85.0 & 6724.0 & 7225.0 & 6970.0 \\
\hline 11 & 70.6 & 75.0 & 4984.3 & 5625.0 & 5295.0 \\
\hline 12 & 78.6 & 84.0 & 6177.9 & 7056.0 & 6602.4 \\
\hline 13 & 86.6 & 82.0 & 7499.5 & 6724.0 & 7101.2 \\
\hline 14 & 82.0 & 88.0 & 6724.0 & 7744.0 & 7216.0 \\
\hline 15 & 80.6 & 83.0 & 6496.3 & 6889.0 & 6689.8 \\
\hline 16 & 82.6 & 85.0 & 6822.7 & 7225.0 & 7021.0 \\
\hline 17 & 72.0 & 81.0 & 5184.0 & 6561.0 & 5832.0 \\
\hline 18 & 78.0 & 88.0 & 6084.0 & 7744.0 & 6864.0 \\
\hline 19 & 87.3 & 95.0 & 7621.2 & 9025.0 & 8293.5 \\
\hline 20 & 90.6 & 95.0 & 8208.3 & 9025.0 & 8607.0 \\
\hline 21 & 79.3 & 90.0 & 6288.4 & 8100.0 & 7137.0 \\
\hline 22 & 73.3 & 81.0 & 5372.8 & 6561.0 & 5937.3 \\
\hline 23 & 70.0 & 72.0 & 4900.0 & 5184.0 & 5040.0 \\
\hline 24 & 80.0 & 85.0 & 6400.0 & 7225.0 & 6800.0 \\
\hline 25 & 68.6 & 75.0 & 4705.9 & 5625.0 & 5145.0 \\
\hline 26 & 77.3 & 80.0 & 5975.2 & 6400.0 & 6184.0 \\
\hline 27 & 85.3 & 86.0 & 7276.0 & 7396.0 & 7335.8 \\
\hline 28 & 74.0 & 76.0 & 5476.0 & 5776.0 & 5624.0 \\
\hline 29 & 74.0 & 84.0 & 5476.0 & 7056.0 & 6216.0 \\
\hline 30 & 69.3 & 75.0 & 4802.4 & 5625.0 & 5197.5 \\
\hline 31 & 56.0 & 75.0 & 3136.0 & 5625.0 & 4200.0 \\
\hline 32 & 69.3 & 78.0 & 4802.4 & 6084.0 & 5405.4 \\
\hline 33 & 72.6 & 85.0 & 5270.7 & 7225.0 & 6171.0 \\
\hline 34 & 96.6 & 94.0 & 9331.5 & 8836.0 & 9080.4 \\
\hline 35 & 78.0 & 82.0 & 6084.0 & 6724.0 & 6396.0 \\
\hline 36 & 78.0 & 85.0 & 6084.0 & 7225.0 & 6630.0 \\
\hline 37 & 72.0 & 85.0 & 5184.0 & 7225.0 & 6120.0 \\
\hline 38 & 80.6 & 77.0 & 6496.3 & 5929.0 & 6206.2 \\
\hline 39 & 82.0 & 90.0 & 6724.0 & 8100.0 & 7380.0 \\
\hline 40 & 74.6 & 80.0 & 5565.1 & 6400.0 & 5968.0 \\
\hline 41 & 72.6 & 82.0 & 5270.7 & 6724.0 & 5953.2 \\
\hline 42 & 76.6 & 82.0 & 5867.5 & 6724.0 & 6281.2 \\
\hline 43 & 75.3 & 85.0 & 5670.0 & 7225.0 & 6400.5 \\
\hline 44 & 74.6 & 75.0 & 5565.1 & 5625.0 & 5595.0 \\
\hline 45 & 85.3 & 90.0 & 7276.0 & 8100.0 & 7677.0 \\
\hline 46 & 76.6 & 92.0 & 5867.5 & 8464.0 & 7047.2 \\
\hline $\mathrm{N}=$ & $\Sigma X=$ & $\Sigma Y=$ & $\Sigma X^{2}=$ & $\Sigma Y^{2}=$ & $\Sigma X Y=$ \\
\hline 46 & 3586 & 3832 & 282439 & 320670 & 300256 \\
\hline
\end{tabular}


After being analyzed further, it has been determined that the correlation index (ro $=0.73$ ) is pointed in the interval of $0.70-0.90$, it means that the correlation refers to "high correlation". In other words, there is a significance correlation in the degree of high correlation between variable $\mathrm{X}$, motivation and variable $\mathrm{Y}$, speaking skills. Degree of Freedom and its significant critical value was applied to prove the result of data calculation above. From the result of previous calculation, the value of ro is 0.73 ; $d f$ is 44 . The scores were compared with the $r t$ at the degree of significance $5 \%$ $(0.2875)$ and $1 \%(0.3721)$ to attest that the correlation between EFL learners' motivation and their speaking skills is significant based on the hypothesis (ro : $r t=$ $0.7300>0.2875$; $r o: r t=0.7300>0.3721$ ). Therefore, the null hypothesis $(\mathrm{Ho})$ of the research is rejected and alternative hypothesis $(\mathrm{Ha})$ is accepted. The meaning of this hypothesis is that there is a significance correlation between EFL learners' motivation and their speaking skills.

\section{Discussion}

Most of the time in language classrooms, EFL learners do not want to speak for a number of reasons, including the fear of making a mistake, the fear of their teachers, feeling embarrassed if their peers laugh at their mistakes, low self-esteem and confidence, a lack of vocabulary and fluency, setting unrealistic goals, such as being as good as a native speaker, negative self-perceptions of language competence, and teachers' negative demeanor and attitude. Therefore, motivation has a significant role to ruin all of reasons why learners do not want to speak. Prior to the analysis, it had been found out that there is an existing relationship between EFL learners' motivation and their speaking skills. Motivation is important for learners and very influential in their speaking proficiency, EFL learners who have a higher motivation also can speak fluently among they who do not have it. The point that motivation is important for them who want to learn especially in speaking. They need to put their motivation in their social life because it recognizes them as their own abilities. Learners who have a motivation, they also have an optimist to do something. Moreover, they can be more active especially in learning activities. Concerning to the definition, Santrock (2006) stated that motivation involves the processes that energize, direct, and sustain behavior. That motivated behavior is behavior that is energized, directed and sustained. Moreover, According to Florez \& Cunningham (1999), speaking is the ability that requires the process of communicative competence, pronunciation, intonation, grammar, and vocabulary improvement. It means that there is a high opportunity of existing relationship that motivate, energize, direct, and sustain EFL learners to speak more intensely and trigger their speaking performance much better.

Motivation has two identifiable components, a need and a drive. Needs, on the other hand, are based on some deficit within the person. The deficit may be determined by physiological involving water, food, sex, sleep, and warmth or the deficit may be also psychological such as approval, affection, power, praise, and prestige but in either case the deficit must lie within the person. Drives, on other hand, though certainly based on needs, have the added feature of an observable change in behavior. Drives imply motion of some sort (Sprinthall \& Sprinthall, 1990). Related to the EFL learners' speaking skills, need involving approval, affection, power and prestige can be very determinant to push learners to speak. It can be emphasized that If the learners are given or stimulated by particular approval, more 
affection, power, some praises and higher prestige to trigger their speaking skills, they will be able to enhance their performance of speaking skills intensely. Moreover, extrinsic motivation is often influenced by external incentives such as reward and punishment. Intrinsic motivation involves the internal motivation to do something for its own sake (Santrock, 2006). It cannot be denied that extrinsic and intrinsic motivation is very determinant in EFL learners' speaking skills. Extrinsic motivation to get good grade is the prove that EFL learners may practice their speaking performance hard in order to obtain a good grade in the course. Intrinsic motivation of pleasure is the prove that EFL learners may practice their speaking performance hard because they enjoy the speech of the course. Speaking will be far more longlasting when it is sustained by intrinsic motivation and when it is driven by the more transitory push of external reinforcers. However, that extrinsic motivation may be necessary to get the learners to initiate certain actions or to get the speaking process started and off dead center. Intrinsic motivation may require an external reinforcement to get it under way, but once it comes to function autonomously.

Recent research suggests that achievement motivation may be of two types: Autonomous, in which person compares their performance against their previous performance, using internalized standards for comparison and social, in which persons compare their performance against that of others (Gage \& Berliner, 1984). Concerning to the roles of learners themselves as an intrinsic motivation. EFL learners are very motivated to enhance their skills when they compare their speaking performance against their previous speaking performance or other speaking performance. Thus, when there is a comparison of values, learners are more motivated or stimulated to make their speaking performance better.

Concerning to teacher roles as an extrinsic motivation, we can conclude that a classroom context characterized by the autonomy supportive motivation style of EFL teachers is closely related to EFL learners' more self-determined motivational orientation, self-regulation, and higher classroom engagement regarding speaking English. Consequently, focusing on the affective sides of classroom context and its effects on learners' self can be an option for language teachers who want to boost learners' speaking performance and integrate reluctant or reticent EFL speakers into teaching activities. Considering the study findings, we can suggest that EFL teachers should aim to create a motivationally supportive course atmosphere where learners' feel secure, spontaneously engage in speaking activities, and become more autonomous language learners. To create such an environment, the teachers should be primarily attentive to learners' interests and needs, and also organize teaching activities with learners by providing opportunities to learners. They should provide rationales before the activities and informational feedback on learners' oral performance. They should also display empathic behavior towards learners and be more attentive to their feelings. All in all, teachers should focus on learners' intrinsic motives and turn their extrinsic motives into fully internalized goals of learning by supporting learners' self and using instructional activities for speaking.

The previous discussion implies that there is a significant correlation between EFL learners' motivation and their speaking skills influenced by the internal and external factors. It can be seen in findings that the correlation index (ro $=0.73$ ) is in the interval of $0.70-0.90$, this means that the correlation belongs to high correlation. Therefore, the data supported by some arguments and emphasized by the findings 
provide strong evidence that the higher motivation belongs to EFL Learners to speak the better ability they speak.

\section{Conclusion}

This study extends our knowledge that there is a significant correlation between EFL learners' motivation and their speaking skills of learners in SMA Negeri 1 Marisa, Pohuwato Regency, Gorontalo, where correlation coefficient belongs to high correlation. In other words, the assumption views that the higher motivation both extrinsic and intrinsic belongs to EFL learners the better ability they speak. One of difficulties of EFL learners in speaking skills is less of motivation and the teachers should give them a motivation as well. They are able to be more active if they have a lot of motivation in their learning activities. Therefore, the teachers should pay attention more intensely about learners' motivation due to the fact that it has significant roles in improving EFL learners' speaking skills.

\section{References}

Brown, D.H. (2001). Teaching by Principles: An Interactive Approach to Language Pedagogy. New York: Pearson Education Company.

Candlin, C.N., \& Hall, D.R. (2002). Teaching and Researching Speaking. United Kingdom: Pearson Education Limited.

Florez \& Cunningham M. (1999). Improving Adult English language Learners' Speaking Skills. Accessed on $25^{\text {th }}$ December 2016. Available from: http://www.ericdigests.org/2000-3/adult.htm.

Gage, N.L., \& Berliner, D.C. (1984). Educational Psychology Third Edition. London: Houghton Mifflin Company.

Gay L.R. et al. (2006). Educational Research. New Jersey: Pearson Education, Inc.

Kazakova, J.K., \& Shantina, E.M. (2019). The Impact of Socio-cultural Differences on Formation of Intrinsic Motivation: The Case of Local and Foreign Students. Motivation. Journal of Applied Linguistics and Language Research, 65(2), 1-9.

Keshavarzi, A., \& Amiri, H. (2016). The Effect of Teachers' Personality and Corrective Feedback on EFL Learners' Motivation. Journal of Applied Linguistics and Language Research, 30(5), 118-129.

Littlewood W.T. (1984). Foreign and Second Language Learning. Cambridge: Cambridge University Press.

Mehregan, M., \& Jafari-Seresht, D. (2014). The Role of Teacher Feedback in Enhancing Leaner Self-efficacy and Motivation in Computer-assisted Environments. MEXTESOL Journal, 38(3), 1-16.

Nunan, D. (2015). Teaching English to Speakers of Other Language. New York: Routlege

Reinsch, L., \& Shelby, A.N. (1996). Communication Challenges and Needs: Perception of MBA Students. Business Communication Quarterly, 59(1), 36-53.

Santrock, J.W. (2006). Educational Psychology. New York: The McGraw-Hill Companies. 
Sprinthall, N.A., \& Sprinthall, R.C. Educational Psychology. Singapore: McGraw-Hill Book Co.

Top, E. (2009). Motivation Effects of Teacher Strategies from the Teachers and Students. Turkey: Karadeniz Technical University. 